\title{
Edukacja emocjonalna adolescentów - program profilaktyczny ukierunkowany na wspomaganie zdrowia psychicznego
}

\section{KEY WORDS}

adolescence, mental health, emotional development

\begin{abstract}
Kubiak Hanna, Edukacja emocjonalna adolescentów - program profilaktyczny ukierunkowany na wspomaganie zdrowia psychicznego [Emotional Education of Adolescents - A Preventive Program Aimed at Supporting Mental Health]. Kultura - Społeczeństwo - Edukacja nr 2(10) 2016, Poznań 2016, pp. 111-123, Adam Mickiewicz University Press. ISSN 2300-0422. DOI 10.14746/kse.2016.10.9.

Adolescence is a time of particular susceptibility to mental disorders. A programme aimed at facilitating emotional development in teenagers might be an important element of prophylactic psychopathology targeting young people. The activities proposed here are group activities and have several aims: to develop the ability to become self-aware regarding one's emotions and regulate their intensity; to foster an attitude of caring for oneself; and to teach problem-solving. What is of particular significance is shaping young people's habits in being proactive in their personal development.
\end{abstract}

\section{Podstawy teoretyczne programu edukacyjnego}

Adolescencja jest czasem przejścia pomiędzy dzieciństwem i dorosłością. Istotą tego okresu rozwojowego są zmiany, a ich zaistnienie i zaadaptowanie do nich bywa dla wielu nastolatków trudne (Kendall, 2010). Niektóre cechy funkcjonowania poznawczego adolescentów, jak czarno-białe myślenie, sztywność poznawcza i niepodatność na argumenty, oraz emocjonalnego, jak labilność nastrojów, duża amplituda emocji i dominacja nastrojów negatywnych nad pozytywnymi (Oleszkiewicz, Senejko, 2013), mogą predysponować młodzież do tego, by przeżywać świat bez „warstwy ochronnej” utkanej z dystansu poznawczego, zdolności 
do refleksji i umiejętności przyjmowania różnych punktów widzenia $\mathrm{w}$ ocenie zdarzeń. W tym okresie odnotowuje się zatem wzmożoną podatność na ujawnianie się zaburzeń psychicznych (Oleszkiewicz, Senejko, 2013). Dotyczy to szczególnie zaburzeń afektywnych, jedno- i dwubiegunowych, zaburzeń odżywiania, schizofrenii oraz nadużywania substancji psychoaktywnych (Bancroft, Reinisch, 1990). Impulsywność adolescentów jest jedną z przyczyn stosunkowo często podejmowanych $\mathrm{w}$ tym okresie życia prób samobójczych (Miller, Rathus, Linehan, 2013), których zwerbalizowanym motywem bywa chęć ucieczki od trudnej wewnętrznie sytuacji, od cierpienia, a także dążenie do uważnienia ${ }^{1}$ emocjonalnych doświadczeń. Poza zdiagnozowanymi zaburzeniami psychicznymi u młodzieży w tej grupie wiekowej obserwuje się również częste występowanie problemów $\mathrm{z}$ emocjami, nastrojem, myśleniem w natężeniu subklinicznym, które też obniżają jakość życia dorastających i mogą wpływać na kierunek ich rozwoju. Niektórzy badacze wskazują jednakże, że z drugiej strony „przejściowy charakter adolescencji i cechująca ją nierównowaga czynią z niej dogodny moment interwencji, ponieważ czas zmiany rozwojowej może prowadzić do większej gotowości do «jej» przyjęcia” (Cichetti, Toth, 1996 za: Kendall, 2010).

Poza koniecznym w sytuacji ujawnienia się zaburzeń psychicznych leczeniem, zazwyczaj obejmującym farmakoterapię oraz psychoterapię, warto zaproponować młodym ludziom wsparcie $\mathrm{w}$ przeżywanych przez nich problemach, które adresowane byłoby do szerszej grupy odbiorców i mogło mieć wymiar profilaktyczny. Realizacja zadań rozwojowych przypisanych adolescencji, takich jak kształtowanie indywidualnej tożsamości, budowanie sieci kontaktów społecznych, rozpoczynanie relacji intymnych, uniezależnianie się od rodziny pochodzenia, podejmowanie decyzji edukacyjnych i rozpoczynanie pracy zarobkowej (Purcell i in., 2011), stanowi dla młodych ludzi wyzwanie i potrzebują oni wsparcia nie tylko w realizacji tych zadan, ale i w radzeniu sobie $\mathrm{z}$ emocjami, jakie ono niesie. Wobec powszechności problemów z obszaru zdrowia psychicznego takie umiejętności, jak wychwytywanie niepokojących objawów we własnym funkcjonowaniu, rozpoznawanie dysfunkcjonalnych sposobów myślenia, dbanie o jakość własnego życia, stają się coraz bardziej pożądane. Warto, by dojrzewający uczyli się jak najwcześniej koncentrować własną uwagę, a także myśli, emocje i działania wokół tego, co w życiu wartościowe. Takie ukierunkowanie na rozwój wartości, pozytywnych cech zwiększy prawdopodobieństwo szczęśliwego życia w perspektywie jednostkowej². Dbałość o zdrowie psychiczne adolescentów ma też

\footnotetext{
${ }^{1}$ Pojęcie to oznacza w tym artykule odwrotność unieważnienia, definiowanego przez Linehan i współpracowników jako niedostrzeganie, bagatelizowanie lub pomijanie znaczenia emocjonalnych doświadczeń, por. Miller, Rathus, Linehan, 2013.

${ }^{2}$ Analiza pojęcia szczęścia wykracza poza ramy niniejszego tekstu, por. np. Czapiński, 1992, Loubomirsky 2013.
} 
znaczenie dla całego społeczeństwa, także w wymiarze ekonomicznym, pozwala bowiem ograniczyć koszty związane z konsekwencjami zaburzeń psychicznych młodzieży, na przykład z leczeniem uzależnień, długotrwałą hospitalizacją psychiatryczną, opóźnianiem wejścia na rynek pracy, przemocą domową (Purcell $\mathrm{i}$ in., 2011).

Podsumowując, warto zaproponować młodzieży zajęcia obejmujące edukację emocjonalną ukierunkowaną $\mathrm{z}$ jednej strony na wyposażenie dorastających $\mathrm{w}$ konkretne umiejętności związane $\mathrm{z}$ podnoszeniem jakości życia oraz radzeniem sobie z problemami emocjonalnymi, $\mathrm{z}$ drugiej - na dostarczenie im wsparcia w trudnych sytuacjach życiowych.

Ramy teoretyczne niniejszej propozycji wyznacza teoria poznawczo-behawioralna, ze szczególnym uwzględnieniem tak zwanej trzeciej jej fali, zwłaszcza koncepcji mindfullness, oraz psychologia pozytywna. Ich połączenie stanowi próbę integracji pozornie sprzecznych postaw wobec życiowych trudności; akceptacja (fundament $\mathrm{w}$ koncepcji mindfulness - Kabat-Zinn, 2013) versus aktywne nastawienie do zewnętrznych i wewnętrznych wyzwań (terapia poznawczo-behawioralna). Jak wspomniano, owa sprzeczność jest jedynie pozorna, bowiem zaakceptowanie rzeczywistości takiej, jaką jest, jest źródłem poczucia wolności i siły koniecznej w procesie zmieniania świata (Andre, 2015).

Terapia poznawczo-behawioralna staje się $\mathrm{w}$ przypadku zaburzeń psychicznych coraz częściej terapią z wyboru ${ }^{3}$, a jej potencjał, związany z budowaniem zdrowia psychicznego jako pozytywnej wartości, pozostaje jeszcze nie do końca wykorzystany.

Alford i Beck $(1997,2005)$ sformułowali aksjomaty terapii poznawczej (za: Kokoszko, 2009). Odnoszą się one do kluczowego znaczenia struktur poznawczych dla psychologicznego funkcjonowania osoby. Owe struktury poznawcze, odpowiadające za selekcję, kodowanie i ocenę bodźców oddziałujących na człowieka określa się mianem schematów ${ }^{4}$, a są one odpowiedzialne za nadawanie znaczenia doświadczeniom (Popiel, Pragłowska, 2008, za: Beck, 1967; Yalom, Leszcz, 2006). Owo znaczenie, rozumiane jako subiektywna interpretacja kontekstu sytuacyjnego i relacji między osobą a kontekstem, aktywizuje strategie adaptacyjne osoby w poszczególnych sytuacjach. To osoba, podejmując wysiłek odnalezienia się w konkretnej sytuacji, raczej konstruuje jej znaczenie niż stosuje zastane w rzeczywistości, w której funkcjonuje. „Każda kategoria znaczenia ma implikacje, które są przekładane na specyficzne wzorce emocji, pamięci i zacho-

\footnotetext{
${ }^{3}$ Por. dyrektywy brytyjskiego NICE - National Instituce for Health and Care Excellence (https://pathways.nice.org.uk/) z opracowanymi algorytmami decyzji dotyczącymi podejmowania terapii w przebiegu poszczególnych zaburzeń psychicznych.

${ }^{4}$ Szerzej o znaczeniu pojęcia „schemat” zob. Popiel, Pragłowska, 2008, s. 39 i dalej.
} 
wania”. Poszczególnym zaburzeniom emocjonalnym i/lub psychicznym odpowiadają specyficzne wzorce nadawanych znaczeń (Popiel, Pragłowska, 2008) w obszarze dotyczącym siebie, kontekstu środowiskowego i przyszłości. Terapia zaburzeń w dużej mierze polega na odczytywaniu tych wzorców i rekonstruowaniu ich w ten sposób, by stały się adaptacyjne z punktu widzenia celów i dobrostanu osoby ${ }^{5}$. Odwołując się do klasycznego ${ }^{6}$ modelu A-B-C Ellisa, gdzie A oznacza zdarzenie aktywizujące, B - przekonania, a C - konsekwencje (obejmujące między innymi zarówno reakcje emocjonalne, jak i zachowania), łatwo dostrzec, że obszarem pracy terapeutycznej będzie przede wszystkim kontekst przekonań, które uruchamiają dopiero reakcje emocjonalne czy prowadzą do - adaptacyjnych lub nie - zachowań jednostki. Jednym z podstawowych mechanizmów zmiany jest zatem rozpoznawanie zniekształceń w myśleniu, charakterystycznym dla danej osoby (por. na przykład Leahy, 2008), odróżnianie myśli od faktów i związane z tym urealnienie znaczenia myśli dla zdarzeń (Leahy, 2008; Segal, Williams, Teasdale, 2009), analiza adaptacyjności poszczególnych przekonań, wypróbowywanie odmiennych niż zwyczajowo działań i analiza ich skutków dla przekonań (na przykład Wells, 2010). Realizacja powyższych celów zakłada zbudowanie nawyku przyglądania się własnym stanom, emocjom i myślom. Jest to umiejętność ważna $\mathrm{w}$ procesie dbania o swój dobrostan nie tylko w przypadku doświadczania problemów $\mathrm{z}$ obszaru zdrowia psychicznego, ale $\mathrm{w}$ codziennym życiu - i warto wyposażyć młodzież w te kompetencje. Przyjęcie perspektywy obserwatora w odniesieniu do tego, co dzieje się w ludzkim ciele i umyśle, jest jednym z założeń koncepcji mindfullness, której skuteczność w wymiarze profilaktycznym i leczniczym wielokroć potwierdzono w badaniach (na przykład Kabat-Zinn, 2013).

W ostatnich latach coraz częściej wskazuje się również na wartości płynące z praktycznego zastosowania psychologii pozytywnej (Carson i in., 2010; Meyer i in., 2012; Seligman i in., 2005). To pojęcie stosuje się w odniesieniu do koncepcji ukierunkowanych na to, co w życiu wartościowe, co prowadzi do szczęścia, dobrych emocji, myśli i działań (por. Trzebińska, 2008; Seligman, 2005; Kaczmarek, 2016).

Interwencje oparte na jej założeniach okazują się skuteczne w pracy ukierunkowanej na poprawę jakości życia, wzmocnienie nadziei, odporności i optymi$\mathrm{zmu}$, a $\mathrm{z}$ drugiej strony sprzyjają radzeniu sobie ze smutkiem czy lękiem zarówno w populacji ogólnej, jak i w grupach osób z diagnozami psychiatrycznymi (na

\footnotetext{
${ }^{5}$ Omówienie wszystkich założeń teorii poznawczej i terapii zob. Kokoszko, 2009, a teorii i terapii poznawczo-behawioralnej: Popiel, Pragłowska, 2008.

${ }^{6}$ Model ten powstał w latach 50. XX wieku, jednakże stanowi „szkielet” większości powstających w późniejszym okresie szczegółowych, rozwiniętych modeli poszczególnych zaburzeń psychicznych.
} 
przykład Pietrowsky, Mikuta, 2012). W myśl dialektycznych teorii trzeba, by człowiek na psychicznej mapie zrobił miejsce dla szczęścia i dla nieszczęścia, często bowiem są one dwiema stronami czy aspektami tego samego doświadczenia (Miller, Linehan, Rathus, 2011). Wiedza o tym, w jaki sposób można wykorzystać zdolności ludzkiego umysłu, by żyć szczęśliwie, kultywować wartości uznawane przez siebie za ważne, a jednocześnie nie bać się i nie unikać cierpienia, odnajdować indywidualne ścieżki w ludzkiej wspólnocie, może być przydatna każdemu, zwłaszcza młodym osobom, które doświadczają negatywnych emocji częściej niż pozytywnych (Oleszkiewicz, Senejko, 2013), a które niewielki zasób doświadczeń życiowych skłania do nadawania im szczególnego znaczenia.

„Psychologia pozytywna opiera się na triadzie: przekonania, nauka, praktyka” (Andre, 2015: 11). Z przekonań i wiedzy wypływają wnioski, które zastosowane w praktyce mogą zmienić ludzkie życie. Francuski psychiatra, naukowiec i praktyk uporządkował je w pięć zasad-reguł praktykowania psychologii pozytywnej; można je uznać za fundament proponowanego programu. W przypadku prowadzenia zajęć edukacyjnych ${ }^{7}$ adresowanych do adolescentów można je potraktować jako wprowadzenie, zachętę do pracy nad sobą i zaprezentować na przykład na pierwszych zajęciach. I tak:

[1] „Najważniejsze jest to, co robię, a nie, co wiem”; zatem zmianę przynieść może myśl, jednak jedynie o ile wiąże się z podejmowanym działaniem. Myśli, według założeń teorii poznawczo-behawioralnej, wyzwalają emocje, które z kolei kierują ludzkim działaniem (Kokoszko, 2009). Najtrafniejsze przekonania, jeżeli nie uruchamiają owego łańcucha zależności (myśl-emocje-konsekwencje, na przykład działania), nie zmienią biegu zdarzeń. Kryterium pozwalające odróżnić adaptacyjne myśli i przekonania od będących wskaźnikiem psychopatologii ruminacji jest właśnie potencjał związany $\mathrm{z}$ uruchomieniem prozdrowotnego działania lub jego brak (Wells, 2010);

[2] „Nad szczęściem trzeba się napocić”; jak wynika z badań Loubomirsky’ego (2013), niespełna 20\% ludzi doświadcza szczęścia bez wysiłku i zmagań; pozostali, aby je przeżyć, muszą świadomie pracować, ukierunkowani przez cele związane $\mathrm{z}$ umiejętnością akceptowania swego losu $\mathrm{z}$ jednej strony, a aktywnego jego budowania - $\mathrm{z}$ drugiej (por. dialektyczna teoria behawioralna - Miller, Rathus, Linehan, 2011);

[3] „Wytrwać”; w przypadku każdej umiejętności w miarę upływu czasu jej praktykowanie jest coraz łatwiejsze, a efekty lepsze; dotyczy to również umiejętności związanych ze świadomym i akceptującym przeżywaniem rzeczywistości, czerpaniem z niej przyjemności i odczuwania szczęścia;

${ }^{7}$ Zarys programu takich zajęć zostanie przedstawiony poniżej. 
[4] „Sznur i włókna” - „sznur składa się z mnóstwa włókien; każde z nich osobno jest zbyt delikatne, by unieść coś ciężkiego. Ale splecione razem zmieniają się w sznur, zdolny już unieść lub pociągnąć bardzo duże ciężary (choćby unieść pokrywę nieszczęścia, nawet jeśli jest bardzo masywna)" (Andre, 2015: 16). Założenie to odnosi się zatem do tego, że poszczególne działania, eksperymenty, myśli, także te wprowadzane celowo jako interwencje, mogą wydawać się błahe, mało znaczące, niewystarczająco skuteczne; jednakże zestawione razem modyfikują znacząco sposób odbierania rzeczywistości, styl życia, poziom odczuwanego szczęścia;

[5] „Miejsce dla nieszczęścia” (Andre, 2015: 13-18) ${ }^{8}$. W obliczu życiowych trudności wielu ludzi „odwraca od nich głowy” - zatem próbuje ich nie dostrzegać czy im zaprzeczać. Wyrazem powszechności takiej strategii może być częste promowanie tak zwanego „pozytywnego myślenia”, rozumianego jako wiara w sukces niezależnie od okoliczności. Takie nastawienie musi prowadzić do rozczarowania $\mathrm{w}$ razie nieuniknionych porażek. Niszczy też dystans właściwy obserwacji zdarzeń - wzmaga napięcie związane $\mathrm{z}$ oczekiwaniem na sukces i oddala spokój umysłu oraz prostą radość z niego płynącą.

\section{Program edukacji afektywnej dla adolescentów}

Program edukacyjny oparty na powyższych założeniach zakładałby rozwijanie umiejętności rozpoznawania adaptacyjnych i nieadaptacyjnych znaczeń nadawanych przez młodzież doświadczeniu. W sytuacji, kiedy własne próby rekonstrukcji znaczenia, tak, by stało się adaptacyjne, zawodzą i stają się nieadaptacyjne, korzystnym działaniem jest sięgnięcie po profesjonalną pomoc. Młodzież uczyłaby się rozpoznawania takich sytuacji i zwracania się o wsparcie do życzliwych dorosłych. Jest oczywiste, że dla osób nawykowo stosujących raczej adaptacyjne niż nieadaptacyjne schematy poznawcze zajęcia mogą stanowić jedynie pomoc w korekcie interpretacji w trudnych sytuacjach; dla osób o przeciwnej charakterystyce, podatnych na zaburzenia psychiczne, najważniejszą umiejętnością wyniesioną z programu będzie być może ta związana $\mathrm{z}$ rozpoznawaniem konieczności poproszenia o wsparcie. Istotne, aby taki krok był rozumiany jako wyraz zaradności młodego człowieka i jego kompetencji w zetknięciu z problemem a nie, jak to często bywa, przejawem słabości i źródłem wstydu.

\footnotetext{
${ }^{8}$ Reguły sformułował na podstawie literatury Andre, ich omówienie jest w większości propozycją własną, opartą na założeniach psychologii egzystencjalnej, pozytywnej, teorii poznawczo-behawioralnej, zwłaszcza koncepcji mindfullness.
} 
Uznanie, że sami w dużej mierze odpowiadamy za jakość naszego życia, nie jest niczym nowym. Już starożytni wskazywali, że powściągnięcie umysłu jest najprostszą drogą, by odnaleźć szczęście, a aktywność człowieka winna być ukierunkowana na odnalezienie własnego miejsca $\mathrm{w}$ "kosmicznym porządku świata” (Marek Aureliusz, 2008). Dziś jednak owa praca, związana z kształtowaniem umysłu, nie jest oczywista - zwłaszcza w świetle dostępności tak zwanych „pigułek szczęścia” i oczekiwania na szybkie rezultaty działań (Haidt, 2007). Farmakoterapia może się okazać nieodzowna w przypadku wystąpienia zaburzeń emocjonalnych i psychicznych, niekiedy bywa jedynie - lub aż - pomocna, ale praca nad sobą, rozumiana jako stałe zadanie, ma nad nią przewagę; pomaga nie tylko radzić sobie z objawami zaburzeń, ale może prowadzić do wyznaczenia sensu życia i wyznaczenia jego biegu w inny niż dotąd $\mathrm{d}^{9}$ sposób.

Okres adolescencji może być czasem, w którym młodzi ludzie chętniej niż kiedy indziej podejmą ten wysiłek. Pomimo wspomnianej już wyżej impulsywności przejawianej na płaszczyźnie emocjonalnej i poznawczej, oczekiwania szybkich efektów działania, niechęci do systematycznego wysiłku, związanej ze zmiennością celów i aspiracji, naturalnej dla dojrzewania, młodzież może podjąć trud pracy nad swoim umysłem, a egocentryczna orientacja emocjonalna, właściwa dorastaniu, $\mathrm{w}$ połączeniu $\mathrm{z}$ altruizmem, budząca się zdolność do refleksji i siły do działania, mogą sprzyjać budowaniu motywacji do pracy. Częste w tym wieku skupienie na sobie sprawia, że analiza własnego umysłu, badanie jego możliwości wydaje się młodzieży bardzo ciekawe, a idealizm i altruizm sprawiają, że stosunkowo łatwo pozyskać dorastających dla idei zakładających budowanie wspólnoty z innymi ludźmi, dzielenie się własnymi problemami i radościami, kształtowanie wewnętrznej siły $\mathrm{w}$ oparciu o wartości wykraczające poza to, co jednostkowe. Takie założenia leżą u podstaw koncepcji mindfullness (Kabat-Zin, 2013), a rozwijanie wdzięczności i poczucia wspólnoty z innymi ludźmi mieści się również w obszarze celów psychologii pozytywnej.

W okresie adolescencji szczególnie znaczenie nadawane jest zazwyczaj doświadczeniom przeżywanym $\mathrm{w}$ kontekście kontaktu z rówieśnikami. Także inne korzyści płynące $\mathrm{z}$ uczestnictwa w pracy grupowej, takie jak możność dzielenia własnego doświadczenia, wspomagania własnym umysłem innej osoby i płynące stąd poczucie kompetencji i satysfakcji, łatwość umacniania motywacji do pracy w relacji z innymi ludźmi, konieczność mierzenia się zróżnicowanymi opiniami i emocjami w reakcji na własne wypowiedzi, poczucie „wspólnoty losu” z innymi, wreszcie względy ekonomiczne, przemawiają za taką właśnie formą pracy (Yalom, Leszcz, 2006).

\footnotetext{
${ }^{9}$ Por. uwagi na temat terapii - Haidt, 2007.
} 
Konstruując grupę, warto zaplanować pracę przy uwzględnieniu klasycznych wskazań Betchera i innych (1974), to jest:

- określenie populacji - dobrze, aby adolescenci pracowali w podgrupach dobranych $\mathrm{z}$ uwagi na wiek, to jest pozostawanie przez nich $\mathrm{w}$ okresie wczesnej i późnej adolescencji, co wiąże się z odmiennymi zadaniami rozwojowymi charakteryzującymi te dwa etapy dojrzewania (na przykład budowa tożsamości grupowej versus indywidualnej, uczestnictwo w związku preintymnym versus intymnym, stopniowe przeniesienie poczucia bezpieczeństwa i bliskości płynących z relacji z rodzicami na relacje rówieśnicze, decyzje dotyczące szkoły i zawodu i inne);

- zasoby populacji - wskazano je powyżej, najważniejsze wiążą się z gotowością do autorefleksji, elastycznością i gotowością do „budowania” siebie, co wynika $\mathrm{z}$ faktu, że tożsamość indywidualna dorastających znajduje się w procesie dynamicznego kształtowania; zestawienie wątków egocentrycznych $\mathrm{z}$ idealizmem skutkuje niepowtarzalną w porównaniu do okresu całego życia podatnością na zmiany - por. Kendall, 2010;

- otoczenie - przyjazne, intymne, nienaznaczające, lepiej poza szkołą, na przykład w domu kultury;

- hetero - versus homogeniczność - grupa homogeniczna pod względem wieku, a heterogeniczna pod względem płci i ewentualnych problemów ${ }^{10}$ może okazać się bardziej inspirująca i pozwala dostrzec więcej nieoczywistych rozwiązań poszczególnych problemów, dzięki odmiennym perspektywom i doświadczeniom poszczególnych uczestników;

- ramy czasowe - krótszy cykl spotkań może okazać się efektywniejszy niż dłuższy, wzbudza bowiem motywację do pracy od pierwszych zajęć, sprawia, że łatwiej podejmować zadania zamiast odkładać je na później, jak miałoby to miejsce w przypadku regularnych spotkań, których liczba jest nieokreślona ${ }^{11}$ : można zaproponować na przykład osiem spotkań grupowych 90-minutowych;

- czynniki „leczące” w grupie - zostały opisane przez klasyków terapii grupowej: Irvina Yalom i Molyn Leszcz (2006) - są to między innymi:

o zaszczepienie nadziei - odgrywa zasadniczą rolę w każdej terapii lub pracy nad własnym rozwojem; może dotyczyć radzenia sobie z życiowymi trudnościami przeżywanymi aktualnie, ale także - bardziej uogólnio-

${ }^{10}$ Autorka prowadziła grupy zarówno homo- jak i heterogeniczne pod względem problemów z obszaru psychopatologii i, poza pewnymi ograniczeniami, jest raczej zwolenniczką heterogennych grup; należy jednakże uwzględnić zastrzeżenie Geldard (Geldard, 2005), dotyczące ostrożności we włączaniu w grupę osób po traumatycznych doświadczeniach, zwłaszcza związanych z wykorzystaniem seksualnym.

${ }^{11}$ Por. np. zasady ustalania spotkań w VIPP-SD. 
ne można odnieść do przebiegu życia w ogóle (będzie „raczej dobrze niż źle"),

o uniwersalność - pozwala uporać się z niepokojącą świadomością własnej wyjątkowości w obliczu trudności,

o udzielanie informacji - $w$ rozumieniu psychoedukacji, dotyczy wyposażania uczestników $\mathrm{w}$ wiedzę rozumianą jako narzędzie przydatne $\mathrm{w}$ radzeniu sobie $\mathrm{z}$ trudnościami,

o altruizm - „członkowie grupy zyskują poprzez dawanie”,

o rozwój umiejętności społecznych - ważne szczególnie w kontekście wieku uczestników, kiedy te umiejętności decydują pośrednio o poziomie zadowolenia z życia,

o naśladowanie - kiedy modelem staje się nie tylko terapeuta, ale również inni członkowie grupy,

o interpersonalne uczenie się - adolescenci mogą uczestniczyć w różnorodnych interakcjach i z tej rozmaitości czerpać,

o katharsis - grupa dostarcza okazji do bezpiecznego przeżywania i okazywania emocji, niosąc równocześnie wsparcie ${ }^{12}$.

- cele grupy - odnoszą się do różnych aspektów funkcjonowania młodzieży, na przykład cele społeczne (budowanie wspólnoty), cele związane z kształtowaniem tożsamości (włączanie w system Ja trudnych doświadczeń), cele emocjonalne (zwiększanie świadomości emocji, obserwowania ich u siebie i innych).

Bardziej szczegółowe cele określa się we współdziałaniu z uczestnikami zajęć; mogą one dotyczyć na przykład dostarczania i udzielania sobie wsparcia w przeżywanych emocjach, na przykład lęku, smutku, opowiadania osobistych historii dotyczących sytuacji trudnych i radzenia sobie z nimi, uczenia się monitorowania własnych stanów emocjonalnych i myśli, planowania działań i inne;

- liczba uczestników - 8-10 osób tworzy grupę wystarczająco liczną, by zwiększyć szansę uczestnika na spotkanie osoby o odpowiadającym mu temperamencie czy charakterze, zapewnić odpowiednią dynamikę grupy i zagwarantować pracę nieprzerywaną przez nieobecności związane $\mathrm{z}$ wypadkami losowymi poszczególnych osób (na przykład choroba), z drugiej umożliwia prowadzącym reagowanie na potrzeby każdego członka grupy i daje każdemu uczestnikowi wystarczającą ilość czasu na opowiedzenie o własnych problemach.

Planując oddziaływania, można zaproponować uczestnikom program pracy, strukturę zajęć, sposób osiągania celów. Z doświadczeń autorki wynika jednak, że

${ }^{12}$ Czynniki te zostały opisane szerzej w Yalom, Leszcz, 2006, a skomentowane w Kubiak, 2013. 
w wielu sytuacjach korzystniejsze jest zadbanie o równowagę między gotowością do prowadzenia grupy a podążania za nią. Dotyczy to zarówno aktywności prowadzącego $\mathrm{w}$ trakcie pojedynczych zajęć, jak i kształtowania programu pracy całej grupy. Wymaga to większej elastyczności prowadzącego, jednakże wpływa korzystnie na motywację uczestników, którzy mają słuszne wrażenie, że są współautorami zajęć. Zadaniem prowadzącego jest wtedy przygotowanie wiodących tematów spotkań, propozycja otwierających pytań czy interwencji, a także komentowanie pojawiających się treści w świetle obranej teorii wiodącej ${ }^{13}$. Dobór treści może wyglądać na przykład następująco

[1] Psychologia pozytywna - przedstawienie jej podstawowych założeń (por. wyżej) i wybranej, najlepiej jednej, interwencji - na przykład „Dziennik dobrych zdarzeń" - prosimy uczestników, by każdego dnia odnotowywali zdarzenia, które ich ucieszyły albo okazały się z ich punktu widzenia korzystne (jest to klasyczne, często opisywane ćwiczenie, por. na przykład Andre, 2015, Kaczmarek, 2016 za Magyar-Moe, 2009), „Dziennik wdzięczności” - wprowadzenie zwyczaju przypominania sobie na przykład wieczorem zdarzeń $\mathrm{z}$ danego dnia, za które można być wdzięcznym - Andre, 2015, „List wdzięczności” - propozycja napisania listu do osoby, wobec której możemy odczuwać wdzięczność - Andre, 2015.

[2] Przekonania a dobrostan - warto wiedzieć, jakimi przekonaniami dotyczącymi siebie, innych, świata, przyszłości kierują się młodzi ludzie. Proces ich odkrywania może być wspaniałą przygodą. Każdy dotrze do przekonań na innym poziomie głębokości. Nauczenie pytania siebie samego w różnych sytuacjach: Co to dla ciebie znaczy? ${ }^{14}$ może pomóc docierać młodym ludziom do wiedzy o sobie samym, buduje to też dystans do różnych trudnych sytuacji. Można wykorzystać również tabelę przekonań dotyczących świata, ludzi i siebie samego (Leahy, 2010), a po jej wypełnieniu analizować z młodzieżą, które przekonania jej służą, które warto w przyszłości być może zmienić, a na razie przynajmniej kwestionować (na przykład czy służą ci przekonania, że trzeba uważać, bo inni chcą cię wykorzystać, albo te, że inni o ciebie zadbają, możesz być spokojny itp.).

[3] Dyskusja z samym sobą - jako kontynuacja wątku dotyczącego podważania, kwestionowania czy analizowania przekonań. Warto wykorzystać technikę zmiany ról czy krzeseł po to, by młodzi ludzie, dyskutując $z$ własnymi opiniami z perspektywy oponenta, nabierali zwyczaju uwzględniania różnych perspektyw w poszczególnych sytuacjach.

\footnotetext{
${ }^{13}$ Kendall proponuje pojęcie teorii wiodącej, by zaznaczyć, że nie ma „idealnej” czy „najlepszej” teorii wyjaśniającej ludzkie zachowania, a sięgamy po koncepcje jak po narzędzie - w miarę potrzeb konkretnych osób.

${ }^{14}$ Por. „Techniki poznawcze” Leahy.
} 
[4] „Zmienić się - to nie jest skomplikowane” (Andre, 2013) - warto urealnić znaczenie pojęcia „zmiana” i wskazać, że jej zaistnienie jest bardziej konsekwencją decyzji niż przypadku. Jedną z dowiedzionych dróg wprowadzenia zmiany jest regularne przyglądanie się sobie, po to, by obserwować siebie, poznać i zrozumieć. Coraz więcej badań wskazuje na skuteczność uważności, czyli zdolności do intencjonalnego skupiania uwagi na strumieniu doświadczeń, które się pojawiają i zmieniają każdej kolejnej chwili, która podlega obserwacji. Efektem ćwiczenia uważności jest rozwój tzw. decentracji (zdolności obserwowania własnych doświadczeń bez angażowania się w jego analizę) i akceptacji (otwartości na aktualne doświadczenie bez względu na jego emocjonalne znaczenie) - (por. Jankowski, Hołas, 2009). Warto zaproponować grupie proste ćwiczenia z uważności ${ }^{15}$.

[5] Rozwój poprzez trudności - pokonywanie, a nawet samo znoszenie trudności jako szansa na rozwój. Pytania o korzyści wyniesione z sytuacji problemowej to jedne z częściej stawianych pytań z perspektywy psychologii narracji (Morgan, 2011). Poszukiwanie odpowiedzi na nie może pomóc dostrzec niedostrzegane początkowo pozytywne aspekty trudnej sytuacji i tego, jak się w niej odnajdujemy.

[6] Poszukiwanie własnych zasobów - w celu pomocy młodym ludziom uświadomienia im ich mocnych stron można wykorzystać ćwiczenie zaczerpnięte $\mathrm{z}$ psychologii poznawczo-behawioralnej, kiedy na przykład prosimy osoby, by zagrały rolę własnego adwokata, usprawiedliwiając trudności i wskazując na to, co warte kontynuowania i zaznaczenia (Leahy, 2008). Nawet jeśli to zadanie wydaje się bardzo proste, a jego efekty oczywiste, to pozytywna prezentacja siebie w kontekście społecznym, uzyskane zazwyczaj wzmocnienia, budują poczucie siły i pewności siebie

[7] „Zrobić coś starego po nowemu zupełnie”16 - co pozwala opuścić ścieżki nawykowego reagowania i rozwija zwyczaj refleksyjnego działania. Eksperymenty mogą odbywać się jedynie w wyobraźni lub w warunkach rzeczywistych (Kendall, 2010; Wells, 2010). Istotne, aby omówić z młodzieżą skutki odejścia od nawyku, które pojawiają się na różnych płaszczyznach - w warstwie poznawczej, emocjonalnej i w działaniu.

[8] Na drodze zmiany - ukazanie życia jako drogi pełnej zmian (,jedyna pewna rzecz w życiu to zmiana") ${ }^{17}$. Warto przyjrzeć się indywidualnej to-

\footnotetext{
${ }^{15}$ Warunkiem tej propozycji są kompetencje prowadzącego, rozumiane jak w Germer i in., 2015.

${ }^{16}$ Określenie pochodzi z piosenki VooVoo pt Po godzinach z płyty Dobry wieczór.

${ }^{17}$ Por. Kabat-Zinn, 2013.
} 
lerancji na zmianę i omówić różnice indywidualne między poszczególnymi osobami w tym obszarze przy uwzględnieniu różnic temperamentalnych. Można wskazać, że poszczególne wybory osób wiążą się $\mathrm{z}$ różnym prawdopodobieństwem doświadczania zmian (na przykład wybór zawodu), jednakże niektórych, może najważniejszych, nie można przewidzieć ani kontrolować.

Zajęcia edukacyjne przeprowadzone według podobnego ${ }^{18}$ planu mogą stanowić dla młodych ludzi punkt wyjścia na ścieżce rozwoju osobistego. Najważniejsze, aby dostrzegli oni, że ten rozwój jest wynikiem decyzji, której podjęcie lub nie - zależy od każdego człowieka. Inspirującą odpowiedzią na ewentualne wątpliwości dotyczące trudności w wyborze tej drogi w sytuacji trudnych okoliczności życiowych pozostaje zdanie Victora Frankla (2011) „Człowiek zdolny jest zmienić świat na lepsze tylko wtedy, gdy jest to możliwe, może natomiast zmienić siebie na lepsze zawsze, gdy tylko jest to konieczne".

\section{Literatura}

Andre Ch. (2013). Niedoskonali, wolni, szczęśliwi. Warszawa.

Andre Ch. (2015). I nie zapomnij być szczęśliwy. Warszawa.

Bancroft J., Reinisch J. (1990). Adolescence and Puberty. New York.

Betcher H. Maple F. Wallace H. (1974). Group Composition. Ann Arbor.

Carson J., Muir M., Clark S., Wakely E., Chander A. (2010). Piloting a gratitude intervention in a community mental health team. "Groupwork" 20(3), s. 73-87

Frankl V. (2011). Człowiek w poszukiwaniu sensu. Warszawa.

Geldard K., Geldard D. (2005). Jak pracować z dziecięcymi grupami terapeutycznymi. Gdańsk.

Haidt J. (2007). Szczęście. Od mądrości starożytnych po koncepcje współczesne. Gdańsk.

Jankowski T., Holas P. (2009). Poznawcze mechanizmy uważności i jej zastosowanie w psychoterapii. „Studia Psychologiczne” 47, 4, s. 59-79.

Kabat-Zinn J. (2013). Życie piękna katastrofa. Warszawa.

Kaczmarek Ł. (2016). Pozytywne interwencje psychologiczne. Dobrostan a zachowania intencjonalne. Poznań.

Kendall P. (2010). Terapia dzieci i młodzieży. Kraków.

Kokoszko A. (2009). Wprowadzenie do terapii poznawczo-behawioralnej. Kraków.

Leahy R. (2008). Techniki terapii poznawczej. Kraków.

Loubomirsky S. (2013). Mity o szczęściu. Warszawa.

Marek Aureliusz. (2008). Rozmyślania do samego siebie. Kęty.

Meyer P.S., Johnson D.P., Parks A., Iwanski C., Penn D.L. (2012). Positive living: a pilot study of group positive psychotherapy for people with schizophrenia. "Journal of Positive Psychology" 7(3), s. 239-248.

\footnotetext{
${ }^{18} \mathrm{~W}$ założeniu prowadzenie zajęć wiąże się z konieczną elastycznością prowadzącego, dlatego plan
} może się zmieniać w zależności od potrzeb grupy i możliwości prowadzącego. 
Miller A., Rathus J., Linehan M. (2011). Dialektyczna terapia behawioralna nastolatków z tendencjami samobójczymi. Kraków.

Morgan A. (2011). Terapia narracyjna. Wprowadzenie. Warszawa.

Oleszkiewicz A., Senejko A. (2013). Psychologia dorastania. Warszawa.

Pietrowsky R., Mikutta J. (2012). Effects of positive psychology interventions in depressive patients a randomized control study. "Psychology" 3(12), s. 1067-1073

Popiel A., Pragłowska E. (2008). Psychoterapia poznawczo-behawioralna. Warszawa.

Purcell R., Goldstone S., Moran J., Albiston D., Edwards J., Pennell K., McGorry P. (2011). Toward a twenty-first century approach to youth mental health care. "International Journal of Mental Health" 40(2), s. 72-87.

Segal Z., Williams M., Teasdale J. (2009). Terapia poznawcza depresji oparta na uważności. Kraków. Seligman M.E.P., Steen T.A., Park N., Peterson C. (2005). Positive psychology progress: empirical validation of interventions. "American Psychology" 60(5), s. 410-421.

Trzebińska E. (2008). Psychologia pozytywna. Warszawa.

Wells A. (2010). Terapia poznawcza zaburzeń lękowych. Kraków.

Yalom I., Leszcz M. (2006). Psychoterapia grupowa. Teoria i praktyka. Kraków. 
